\title{
Challenging management of obturator hernia: a report of three cases and literature review
}

\author{
Kazım Şenol, M.D., Mehmet Emrah Bayam, M.D., Uğur Duman, M.D., Evren Dilektaşlı, M.D., \\ Muhammed Doğangün, M.D., Abdullah İnal, M.D., Deniz Necdet Tihan, M.D.
}

Department of General Surgery, Şevket Yılmaz Training and Research Hospital, Bursa-Turkey

\begin{abstract}
Obturator hernia $(\mathrm{OH})$ is a rare condition with high rates of morbidity and mortality. While diagnosis is difficult, surgery is the definitive treatment. Intestinal obstruction is the most common symptom upon admission. In addition, small-bowel obstruction is documented in more than half of $\mathrm{OH}$ patients.Advanced age, intestinal obstruction, bowel perforation, comorbid diseases, and clinical deterioration are risk factors for higher rates of mortality. The aim of the present report was to document clinical and surgical management of 3 female patients, each over 80 years of age, admitted to the emergency surgery department with intestinal obstruction and $\mathrm{OH}$.
\end{abstract}

Keywords: Computed tomography; mortality; obturator hernia; small-bowel obstruction.

\section{INTRODUCTION}

Obturator hernia $(\mathrm{OH})$ is a rare clinical entity with an incidence between $0.05-1.4 \%$ of all hernias. ${ }^{[1]}$ Excessive weight loss and multi-parity in women, chronic obstructive pulmonary disease, increased intraabdominal pressure associated with chronic constipation, and ascites are risk factors for obturator canal enlargement leading to the development of peritoneal dimple and invagination of a peritoneal sac into the obturator canal. ${ }^{[2]}$ Clinical characteristics of $\mathrm{OH}$ are obscure. Lack of significant examination findings and clinical symptoms usually increase rates of morbidity and mortality. Although Howship-Romberg sign (HR) is the pathognomonic finding of a compressed obturator nerve by internal rotation of the hip, only 15-50\% of patients present with pain in the medial part of the thigh. [3] Hannington-Kiff (HK) sign, characterized by the absence of adductor thigh reflex, is another specific finding of $\mathrm{OH}_{.}{ }^{[4]}$ In addition to obturator neuralgia and lower abdominal pain, intestinal obstruction is the most significant clinical manifestation.

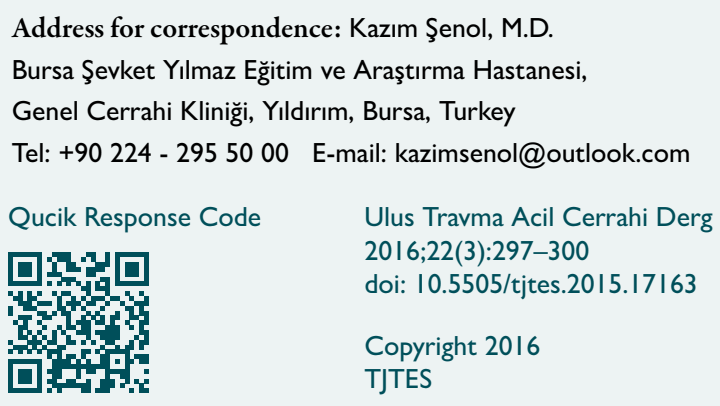

The aim of the present report was to provide a review of clinical presentations of 3 patients with $\mathrm{OH}$, as well as a clinical perspective, even in challenging diagnosis with complicated clinical courses.

\section{CASE REPORT}

Case I- An 83-year-old woman was admitted to the department of emergency surgery with vomiting, nausea, and obstipation that had lasted 4 consecutive days. Medical history was unremarkable. On physical examination, she had tenderness throughout the abdomen without defense or rebound. $H R$ sign, HK sign, and related obturator neuralgia was not observed. Laboratory parameters were within normal range. Direct abdominal x-ray graphs showed small-bowel obstruction, and initial computed tomography (CT) scan aided in diagnosis of right-sided, incarcerated $\mathrm{OH}$ (Fig. I). The patient underwent emergency surgery with midline laparotomy. Exploration of the abdomen revealed a $5-\mathrm{cm}$ ileal segment 60 $\mathrm{cm}$ above the ileocecal valve, incarcerated through the obturator canal. Gentle traction of the hernia sac and incarcerated bowel was performed to avoid iatrogenic perforation of the ileal segment. The strangulated ileal segment was gangrenous (Fig. I). Following segmentectomy and anastomoses, obturator defect was repaired with interrupted sutures. Postoperative follow-up was uneventful, and the patient was discharged on the tenth postoperative day.

Case 2- An 89-year-old woman was admitted to the department of emergency surgery with lower abdominal pain and obstipation that had begun 2 days prior. The patient had a 

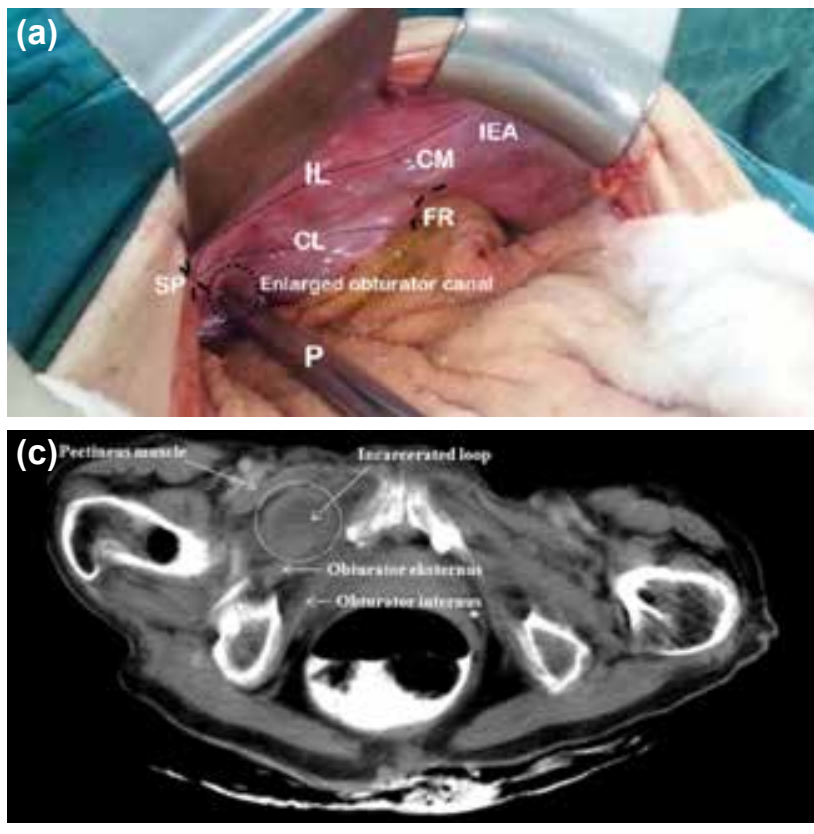

history of appendectomy and left inguinal hernia repair. Physical examination revealed tenderness in the lower quadrants of the abdomen and mild abdominal distention. Rectal examination was normal. Laboratory tests showed leukocytosis, hyponatremia, and hypokalemia. Direct $x$-ray graphs and abdominal ultrasonography showed unperistaltic dilated intestines. Oral intake was stopped, and initial therapy with serial physical examination check-ups was planned. On the second day, direct $x$-ray graphs showed increased obstruction of the small intestine with findings of severe peritonitis. Exploratory laparotomy revealed incarcerated ileal segment 100 $\mathrm{cm}$ above the terminal ileum, through a large obturator canal. Strangulated ileal segment was gangrenous, and perforation was limited to the obturator canal. Hence, resection anastomosis was performed. Necrotic tissue and bowel contents in the obturator canal were removed with radical debridement. Obturator canal was closed with interrupted sutures, and a sump drain was placed in the rectovesical space. Postoperative follow-up was uneventful. On the fifth postoperative day, oral intake was resumed, and abdominal drain was removed. The patient was discharged on the tenth postoperative day with favorable outcome.

Case 3- An 8I-year-old woman was admitted with fecaloid vomiting and recurrent lower abdominal pain. Abdominal distention had begun 3 months prior, and slight amounts of watery defecation had occurred 2 or 3 times per week. Medical history included 2 caesarian sections and appendectomy operations. Physical examination revealed tenderness with findings of peritonitis, distention, and hyperactive bowel sounds. Rectal palpation demonstrated a painful mass externally compressing the rectal mucosa into the anal canal. White blood cell count was 14500 cells $/ \mu \mathrm{L}$, and serum amylase level was 2 times higher than normal limits. Direct abdominal x-ray graphs showed dilated small-bowel loops and multiple air-

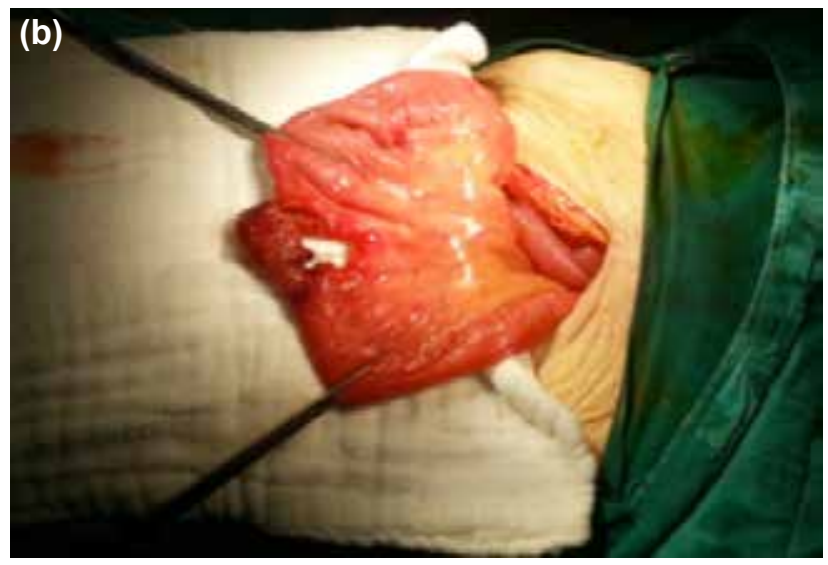

Figure 2. (a) Peroperative exploration of enlarged obturator canal and illustration of anatomical indexes. (b) Strangulated and gangrenous small-bowel segment with complete detachment form mesentery. (c) Computed tomography scan showing incarcerated intestinal loop through the right obturator canal. CL: Cooper ligament; CM: Corona mortis; FR: Femoral ring; IEA: Inferior epigastric artery; IL: Inguinal ligament; P: Surgical clamp; SP: Symphysis pubis.

fluid levels. Medical therapy was planned and initial decompression was maintained by nasogastric tube insertion. Further investigation with oral and rectal contrast-enhanced CT demonstrated a right-sided $\mathrm{OH}$ with small-bowel strangulation. Midline laparotomy confirmed the diagnosis. Strangulated intestines were firmly adherent, and careful traction did not reduce the hernia sac. Adhesions between the peritoneum and the obturator membrane were dissected with careful cauterization. A nelaton catheter was inserted through the obturator foramen along the obturator canal, and hydrostatic pressure was maintained using slight infusion of isotonic saline solution with 50-cc syringe. Hence, hernia sac and intestines were reduced by gentle means, without perforation or ischemia. Consequently, obturator defect was repaired with interrupted sutures. Postoperative follow-up was uneventful. Nasogastric tube was removed on the second day, and oral intake was initiated. The patient was discharged on the eighth day, with full recovery.

\section{DISCUSSION}

$\mathrm{OH}$ commonly occurs in elderly, emaciated, multiparous women, with a female:male ratio of $9: 1,{ }^{[5,6]}$ Acute intestinal obstruction is the most significant clinical presentation, present in over $90 \%$ of $\mathrm{OH}$ patients. ${ }^{[2]}$ Approximately half present with small-bowel strangulation. ${ }^{[7]}$ In addition, $\mathrm{OH}$ may contain the large bowels, omentum, appendix, or fallopian tubes. ${ }^{[8,9]}$ Other clinical symptoms include lower abdominal pain, abdominal distention, nausea, vomiting, and obturator neuralgia, associated with intestinal ischemia, all of which are non-specific findings ranging from mild to severe. ${ }^{[2]}$ Unfortunately, these symptoms in isolation are not sufficient for differential diagnosis.

In the clinical setting, even with strong clinical suspicion, ap- 
proximately $10 \%$ of patients are diagnosed prior to surgery. ${ }^{\left[{ }^{10]}\right.}$ Better diagnostic performance with higher sensitivity and specificity rates are demonstrated by $\mathrm{CT}$, as opposed to ultrasonography, direct abdominal $\mathrm{x}$-ray radiographs, or magnetic resonance imaging. ${ }^{\left[{ }^{[1]}\right.} \mathrm{CT}$ is relatively non-invasive, a fast and reliable tool, with a preoperative diagnosis rate of $90 \%$. ${ }^{[12]} \mathrm{CT}$ is thus defined as a gold standard, first-line imaging modality, particularly in cases of acute intestinal obstruction when supported with direct abdominal x-ray radiographs and subtle clinical presentation of $\mathrm{OH}_{0}{ }^{[13]}$

However, it has been noted in recent studies that preoperative CT plays a controversial role in postoperative outcomes. Kammori et al. have suggested that preoperative $\mathrm{CT}$ reduced both intestinal resection rates and surgical mortality, ${ }^{[14]}$ whereas Yokoyoma et al. reported insignificant impact on patient outcome. ${ }^{\left[{ }^{[1]}\right]}$ In the cases presently described, initial CT evaluation revealed intestines incarcerated into the obturator canal in all cases. Compared to examination findings, CT provided a definitive diagnosis, allowing for the performance of prompt and accurate treatment. Therefore, preoperative CT should be used as a primary screening tool for differential diagnosis of intestinal obstruction, particularly in elderly, emaciated, and multiparous women with high suspicion of $\mathrm{OH}$.

In routine practice, clinical efforts to identify the underlying causes of acute intestinal obstruction usually delay the timing of initial surgical intervention and complicate the clinical course.

It has been argued that prolonged diagnosis of incarcerated $\mathrm{OH}$ leads to an increase of up to $70 \%$ in rates of morbidity and mortality ${ }^{[7]}$ High morbidity rates are also associated with advanced age, bowel perforation, comorbid diseases, and deterioration or disability. ${ }^{[16]}$ Several algorithms have been described for management of suspected $\mathrm{OH}$ to reduce morbidity and mortality. ${ }^{[6,1]]}$ Above all, clinicians should specify admission signs and symptoms of possible $\mathrm{OH}$ presentation with history and physical examination. The next step is to determine peritonitis findings and small-bowel obstruction with direct abdominal $x$-ray graphs and CT scan. Whether or not diagnosis is clear, urgent laparotomy must be performed if intestinal obstruction symptoms persist and/or manifest with peritonitis.

Even with challenging diagnosis in emergent or recurrent $\mathrm{OH}$, surgery is stated as the main treatment. Several surgical procedures have been described, including abdominal, inguinal, retropubic, and obturator approaches. ${ }^{[2]}$ Inguinal, retropubic and obturator approaches are preferred when preoperative diagnosis is clear, and intestinal strangulation is excluded. The aims of surgical intervention should be to evaluate viability of incarcerated organs or intestines for adequate resection and to repair the corrupted obturator canal. The abdominal approach was preferred in the present cases. The patients were examined for intestinal ischemia, and the anatomy of the obturator canal was more properly observed by lower midline laparotomy. In all cases, midline laparotomy and primary repair of the defect resulted in satisfactory postoperative outcomes.

In recent reports, surgeons have been encouraged to perform laparoscopy in cases of $\mathrm{OH}^{\left[{ }^{[17]}\right.}$ Laparoscopic surgery has been recently described as an elective treatment modality in cases of accurate preoperative diagnosis subsequent to CT. Disadvantages of laparoscopic surgery are inability to assess viability or resection of intestines, and inability to perform as an emergency procedure. Some authors have suggested that even in emergent settings with abdominal distention, formal diagnostic laparoscopy should be performed to visualize intestinal viability, and that transabdominal preperitoneal approach should be performed to repair obturator defects. ${ }^{[3]}$

In conclusion, $\mathrm{OH}$ is a clinical entity that an experienced surgeon may rarely identify in routine clinical practice. Clinical signs and symptoms are not specific enough for immediate diagnosis. Obturator neuralgia presenting with intestinal obstruction is the most significant finding upon examination that can lead clinicians with high clinical suspicion to an accurate diagnosis. Among all abdominal wall hernias, $\mathrm{OH}$ has the highest rates of morbidity and mortality. Therefore, fast and accurate diagnosis plays an important role in improving postoperative outcomes. Assessment of elderly, emaciated, multiparous women with lower abdominal pain and abdominal distention should be performed more cautiously, and CT should be promptly performed in cases of potential $\mathrm{OH}$. Whether or not diagnosis is clear, urgent laparotomy must be performed if symptoms of intestinal obstruction persist and/or manifest with peritonitis.

\section{Conflict of interest: None declared.}

\section{REFERENCES}

1. Lo CY, Lorentz TG, Lau PW. Obturator hernia presenting as small bowel obstruction. Am J Surg 1994;167:396-8. Crossref

2. Petrie A, Tubbs RS, Matusz P, Shaffer K, Loukas M. Obturator hernia: anatomy, embryology, diagnosis, and treatment. Clin Anat 2011;24:562-9.

3. Nasir BS, Zendejas B, Ali SM, Groenewald CB, Heller SF, Farley DR. Obturator hernia: the Mayo Clinic experience. Hernia 2012;16:315-9.

4. Hannington-Kiff JG. Absent thigh adductor reflex in obturator hernia. Lancet 1980;1:180.

5. Ziegler DW, Rhoads JE Jr. Obturator hernia needs a laparotomy, not a diagnosis. Am J Surg 1995;170:67-8. Crossref

6. Chang SS, Shan YS, Lin YJ, Tai YS, Lin PW. A review of obturator hernia and a proposed algorithm for its diagnosis and treatment. World J Surg 2005;29:450-4. Crossref

7. Gray SW, Skandalakis JE, Soria RE, Rowe JS Jr. Strangulated obturator hernia. Surgery 1974;75:20-7.

8. Hartley BE, Davies MS, Bowyer RC. Strangulated appendix in an obturator hernia presenting as gas gangrene of the thigh. Br J Surg 1994;81:1135. Crossref

9. Karasaki T, Nakagawa T, Tanaka N. Obturator hernia of the fallopian tube. Abdom Imaging 2013;38:619-21. Crossref 
10. Bjork KJ, Mucha P Jr, Cahill DR. Obturator hernia. Surg Gynecol Obstet 1988;167:217-22.

11. Rodríguez-Hermosa JI, Codina-Cazador A, Maroto-Genover A, PuigAlcántara J, Sirvent-Calvera JM, Garsot-Savall E, et al. Obturator hernia: clinical analysis of 16 cases and algorithm for its diagnosis and treatment. Hernia 2008;12:289-97.

12. Terada R, Ito S, Kidogawa H, Kashima K, Ooe H. Obturator hernia: the usefulness of emergent computed tomography for early diagnosis. J Emerg Med 1999;17:883-6. Crossref

13. Mandarry MT, Zeng SB, Wei ZQ, Zhang C, Wang ZW. Obturator hernia-a condition seldom thought of and hence seldom sought. Int J Colorectal Dis 2012;27:133-41. Crossref
14. Kammori M, Mafune K, Hirashima T, Kawahara M, Hashimoto M, Ogawa T, et al. Forty-three cases of obturator hernia. Am J Surg 2004;187:549-52. Crossref

15. Yokoyama Y, Yamaguchi A, Isogai M, Hori A, Kaneoka Y. Thirty-six cases of obturator hernia: does computed tomography contribute to postoperative outcome? World J Surg 1999;23:214-7. Crossref

16. Hennekinne-Mucci S, Pessaux P, Du Plessis R, Regenet N, Lermite E, Arnaud JP. Strangulated obturator hernia: a report of 17 cases. [Article in French] Ann Chir 2003;128:159-62. [Abstract] Crossref

17. Hunt L, Morrison C, Lengyel J, Sagar P. Laparoscopic management of an obstructed obturator hernia: should laparoscopic assessment be the default option? Hernia 2009;13:313-5. Crossref

\section{OLGU SUNUMU - ÖZET}

\section{Obturator fitıkların zorlu yönetimi: Üç olgu sunumu ve literatürün gözden geçirilmesi}

Dr. Kazım Şenol, Dr. Mehmet Emrah Bayam, Dr. Uğur Duman, Dr. Evren Dilektaşı, Dr. Muhammed Doğangün, Dr. Abdullah İnal, Deniz Necdet Tihan

Şevket Yılmaz Eğitim ve Araştırma Hastanesi, Genel Cerrahi Kliniği, Bursa

Obturator herni yüksek mortalite ve morbidite yüzdeleri ile seyreden nadir görülen bir sağlık sorunudur. Tanı koymak güç olmakla birlikte kesin tedavisi cerrahidir. Bağırsak tıkanıklığı en sık başvuru semptomudur. Bununla birlikte hastaların yarısından fazlasında ince bağırsak tıkanıklığı izlenmektedir. İleri yaş, kadın cinsiyet, eşlik eden kronik hastalıklar, bağırsak tıkanıklığı, bağırsak perforasyonu ve hastanın klinik olarak kötü durumda olması yüksek mortalite için risk faktörleridir. Bu olgu sunumunda, acil cerrahi servise intestinal obstrüksiyon ve obturator herni ile kabul edilmiş 80 yaş üzeri, üç kadın hastanın klinik ve cerrahi yönetimini sunmayı amaçladık.

Anahtar sözcükler: Bilgisayarlı tomografi; ince bağırsak tıkanıklığı; mortalite; obturator herni.

Ulus Travma Acil Cerrahi Derg 2016;22(3):297-300 doi: 10.5505/tjtes.20I5.17163 